\title{
Efektywność egzekucji administracyjnej w Polsce W LATACH 2010-2014
}

\section{Wstęp}

Istota, celem postępowania egzekucyjnego jest zapewnienie skuteczności aktów administracyjnych wydawanych $w$ postępowaniu administracyjnym $\mathrm{w}$ drodze przymusowego wykonania wynikających $\mathrm{z}$ nich obowiązków. Innymi słowy, celem postępowania jest wymuszenie przez organ egzekucyjny zachowania się zgodnego z prawem, polegającego na wykonaniu obowiązków o charakterze pieniężnym lub niepieniężnym, określonych $\mathrm{w}$ akcie prawnym lub powstających z mocy prawa ${ }^{1}$. Postępowanie egzekucyjne to zorganizowany ciąg czynności procesowych podejmowanych przez organy egzekucyjne oraz inne podmioty w celu doprowadzenia do przymusowego wykonania obowiązków objętych egzekucją administracyjną. Podobnie jak postępowanie administracyjne jurysdykcyjne, służy ono urzeczywistnianiu norm prawa administracyjnego ${ }^{2}$.

Postępowanie egzekucyjne jest postępowaniem szczególnym, dość dolegliwym dla dłużnika. Obowiązująca ustawa o postępowaniu egzekucyj-

${ }^{*}$ Dr, Wyższa Szkoła Handlowa w Radomiu; e-mail: piotr.mozylowski@gmail.com

${ }^{1}$ Z. Kmiecik, Postępowanie administracyjne, postępowanie egzekucyjne w administracji i postępowanie sądowoadministracyjne, Warszawa 2014, s. 227; P. Możyłowski, Przedsiębiorca jako zobowiazany w postępowaniu egzekucyjnym w administracji. Wybrane zagadnienia, [w:] P. Możyłowski (red.), Zarządzanie należnościami w sektorze małych $i$ średnich przedsiębiorstw w okresie kryzysu gospodarczego, Radom 2014, s. 203.

2 T. Jędrzejewski, M. Masternak, P. Rączka, Administracyjne postępowanie egzekucyjne, Toruń 2006, s. 27. 
nym w administracji ${ }^{3}$ jest swoistego rodzaju „konstytucją" dla organów administracji publicznej odpowiadających za egzekwowanie należności publicznoprawnych. Ustawa została uchwalona w 1966 r. i od tamtej pory przeszła dość znaczną ewolucję, choć część przepisów można nazwać „,archaicznymi" i niedostosowanymi do dzisiejszej sytuacji społeczno-gospodarczej. Zmiany wprowadzane w ustawie w jakimś stopniu skomplikowały jej strukturę, a zawarte $\mathrm{w}$ niej przepisy nie są łatwe $\mathrm{w}$ stosowaniu, tak dla podmiotów publicznoprawnych (wierzycieli, organów egzekucyjnych), jak i dłużników.

Wymuszenie wykonania ciążących na zobowiązanych obowiązków, w myśl art. 1 ustawy o postępowaniu egzekucyjnym jest jedynym celem postępowania egzekucyjnego ${ }^{4}$. Wyrażona w ustawie zasada celowości winna być przestrzegana przez organy egzekucyjne w toku całego postępowania egzekucyjnego. Efektywność postępowania egzekucyjnego jest ważna z punktu widzenia dochodów budżetowych zarówno państwa, jak i poszczególnych szczebli samorządu terytorialnego. Jak stwierdza M. Karpiuk, zapobiega ono nieuczciwości w zakresie realizacji nałożonych przez państwo i działające w jego imieniu organy administracji publicznej obowiązków, a także przeświadczeniu o braku konieczności podporządkowania się prawu ${ }^{5}$.

Celem niniejszego opracowania jest przedstawienie efektywności należności podatkowych i niepodatkowych. Autor analizując pozyskane dane wskazuje na trudności w efektywnym egzekwowaniu należności przez organy egzekucyjne. $W$ tych rozważaniach oprócz przedstawienia „ułomności” przepisów regulujących postępowanie egzekucyjne zostały również poruszone kwestie bierności wierzycieli. Przedstawione dane świadczą o niskiej świadomości wierzycieli o możliwych formach współpracy z organami egzekucyjnymi oraz o możliwościach zabezpieczenia należności i niskiej efektywności ich wykorzystania. Wnioski wyciągnięte przez autora pokrywają się z tymi, które wynikają z informacji pokontrol-

3 Ustawa z dnia 17 czerwca 1966 r. o postępowaniu egzekucyjnym w administracji, Dz. U. z 2016 r. poz. 599 z późn. zm.

${ }^{4}$ M. Staniszewski, Uciążliwość a skuteczność egzekucji zobowiąań podatkowych, "Zeszyty Naukowe Uniwersytetu Szczecińskiego. Studia Administracyjne” 2011, nr 3 (652), s. 51.

${ }^{5}$ M. Karpiuk, Egzekucja administracyjna należności stanowiących dochód państwa oraz jednostek samorządu terytorialnego na przykładzie województwa mazowieckiego, „Studia Prawnicze i Administracyjne" 2010, nr 1, s. 63. 
nych przeprowadzonych przez NIK . W treści opracowania wyniki analizy tekstów prawnych i przedstawionych danych zostały w niektórych miejscach wzbogacone o uwagi wynikające z praktyki zawodowej autora jako byłego pracownika organu egzekucyjnego. Autorowi nie chodziło ponadto o zajęcie krytycznego stanowiska wobec organów egzekucyjnych czy wierzycieli - choć może się tak czytelnikowi wydawać - ale o zwrócenie uwagi na ten, jak się wydaje, istotny problem, jakim jest efektywność egzekucji. Choć częściowe jego zminimalizowanie może przyczynić się do zwiększenia dochodów własnych budżetu państwa, jak i innych podmiotów publicznoprawnych, takich jak jednostki samorządu terytorialnego.

\section{Efektywność egzekucji administracyjnej}

Najważniejszym, można rzec podstawowym, organem egzekucyjnym jest naczelnik urzędu skarbowego. Jest on uprawniony do stosowania wszystkich środków egzekucyjnych, które zostały wskazane w ustawie o postępowaniu egzekucyjnym $\mathrm{w}$ administracji ${ }^{7}$. Naczelnik urzędu skarbowego, będąc organem egzekucyjnym, ma prawo stosować środki egzekucyjne, które winny doprowadzić do bezpośredniego wykonania obowiązku. Należy wskazać w tym miejscu, iż zgodnie z zasadą wyrażoną w art. $7 \S 2$ ustawy egzekucyjnej, organ egzekucyjny winien stosować środki najmniej uciążliwe dla zobowiązanego. Odnosząc się natomiast do powyższego należy stwierdzić, iż nie zawsze możliwe jest pogodzenie zasady stosowania najmniej uciążliwego środka egzekucyjnego z zasadą celowości czy szybkości postępowania. Często środek egzekucyjny, który prowadzi do bezpośredniego wykonania obowiązku może być środkiem dość dolegliwym dla zobowiązanego. Jednak w tym kontekście należy uwzględnić szeroki interes społeczny nad indywidualnym i obowiązujące

${ }^{6}$ Informacja o wynikach kontroli efektywności egzekucji administracyjnej podatków i opłat dla których ustalania lub określania i pobierania właściwy jest organ gminy, LKI-41014-08, NIK, Delegatura w Kielcach, Kielce, maj 2009; Informacja o wynikach kontroli prawidłowość i skuteczność realizacji przez jednostki samorzadu terytorialnego podatków lokalnych oraz dochodów z majatku, KAP-4101-004-00/2014, NIK, Warszawa 06.03.2015.

${ }^{7}$ Inne podmioty, które z mocy ustawy są również organami egzekucyjnymi mają ustawowo ograniczone uprawnienia do stosowania poszczególnych środków egzekucyjnych; P. Przybysz, Postepowanie egzekucyjne w administracji. Komentarz, Warszawa 2009, s. 107; M. Staniszewski, Egzekucja obowiązków podatkowych, Warszawa 2010, s. 42. 
zasady nakazujące wszystkim ponoszenie obciążeń publicznoprawnych ${ }^{8}$. Podatki i inne daniny publiczne są źródłem dochodów zarówno budżetu centralnego, jak i budżetów samorządowych dlatego tak ważne jest, aby podatnicy wywiązywali się ze swoich obowiązków. W sytuacji niewywiązywania się z nałożonych obowiązków konieczne staje się uruchomienie przez administrację publiczną aparatu przymusu9 . Powszechnie przyjmowanym wskaźnikiem efektywności egzekucji zaległości jest proporcja kwoty wyegzekwowanych zaległości w okresie sprawozdawczym do zaległości objętych tytułami wykonawczymi przekazanymi do realizacji ${ }^{10}$. W tabelach zamieszczonych w opracowaniu wskazano na efektywność egzekucji należności podatkowych i niepodatkowych w latach 2010-2014.

Tab. 1. Efektywność egzekucji należności podatkowych i niepodatkowych w Polsce w latach 2010-2014 (kwoty w tys. zł)

\begin{tabular}{|c|c|c|c|c|c|c|}
\hline Rok & $\begin{array}{c}\text { Liczba } \\
\text { tytułów } \\
\text { wykonaw- } \\
\text { czych do } \\
\text { załatwienia }\end{array}$ & $\begin{array}{c}\text { Kwota } \\
\text { zaległości } \\
\text { objętych } \\
\text { tytułami } \\
\text { wykonaw- } \\
\text { czymi do } \\
\text { załatwienia }\end{array}$ & $\begin{array}{c}\text { Liczba } \\
\text { tytułów } \\
\text { wykonaw- } \\
\text { czych } \\
\text { załatwio- } \\
\text { nych }\end{array}$ & $\begin{array}{c}\text { Kwota } \\
\text { zaległości } \\
\text { wyegzekwo- } \\
\text { wanych }\end{array}$ & $\begin{array}{c}\text { Efektywnośćć } \\
\text { tytułów } \\
\text { załatwionych } \\
4: 2\end{array}$ & $\begin{array}{c}\text { Efektywność } \\
\text { należności } \\
\text { wyegzekwo- } \\
\text { wanych } \\
5: 3\end{array}$ \\
\hline 1 & 2 & 3 & 4 & 5 & 6 & 7 \\
\hline 2010 & 18343 & 17218595 & 6964 & 3752928 & 37,96 & 21,79 \\
\hline 2011 & 19084 & 18160810 & 7523 & 4036842 & 39,42 & 22,22 \\
\hline 2012 & 19764 & 21821443 & 7695 & 4411149 & 38,93 & 20,21 \\
\hline 2013 & 21426 & 23676359 & 8363 & 4404829 & 39,03 & 18,60 \\
\hline 2014 & 20878 & 21474383 & 9415 & 4197294 & 45,09 & 19,54 \\
\hline
\end{tabular}

Źródło: opracowanie własne na podstawie danych uzyskanych z Ministerstwa Finansów

Analizując dane zawarte w Tab. 1 należy stwierdzić, iż efektywność egzekucji w Polsce stanowi dość poważny problem. Jest to problem, który związany jest z ograniczonymi wpływami środków do budżetów właściwych podmiotów. Szczególną uwagę zwraca kwota zaległości objętych tytułami egzekucyjnymi do załatwienia przez naczelników urzędów skar-

${ }^{8}$ W sytuacji niemożności spełnienia świadczeń przez zobowiązanego ustawodawca przewidział instrumenty, które pozwalają dłużnikowi zrealizować je w późniejszym terminie lub nawet w ogóle (raty, zwolnienia, umorzenia).

${ }_{9}$ M. Karpiuk, Egzekucja administracyjna należności, s. 64.

${ }^{10}$ E. Małecka-Ziembińska, Efektywność fiskalna podatku dochodowego od osób fizycznych w Polsce, Poznań 2012, s. 201. 
bowych. Łączna kwota zaległości, która jest dochodzona, wynosi ponad 20 mld zł i wynika z 20 mln tytułów wykonawczych. Jak zatem widać, problem wywiązywania się z obowiązków na rzecz budżetu państwa czy innych podmiotów publicznoprawnych jest dość znaczny. Jego rozwiązanie w znacznej mierze zależy od efektywności egzekucji i stosowanych w tym zakresie środków egzekucyjnych.

Poniżej zaprezentowano dane dotyczące egzekucji poszczególnych należności. Jak wynika z poniższych zestawień, efektywność egzekucji kształtuje się na różnym poziomie, w zależności od tego, jakie zaległości są dochodzone. Chodzi m.in. o to czy są to zaległości z tytułu podatków stanowiących dochód budżetu państwa i jednostek samorządu terytorialnego czy może należności niepodatkowych, takich jak grzywny, mandaty.

Tab. 2. Efektywność egzekucji podatków stanowiących dochód Budżetu Państwa w latach 2010-2014 (kwoty w tys. zł)

\begin{tabular}{|c|c|c|c|c|c|c|}
\hline Rok & $\begin{array}{c}\text { Liczba } \\
\text { tytułów } \\
\text { wykonaw- } \\
\text { czych do } \\
\text { załatwienia }\end{array}$ & $\begin{array}{c}\text { Kwota } \\
\text { zaległości } \\
\text { objętych } \\
\text { tytułami } \\
\text { wykonaw- } \\
\text { czymi do } \\
\text { załatwienia }\end{array}$ & $\begin{array}{c}\text { Liczba } \\
\text { tytułów } \\
\text { wykonaw- } \\
\text { czych } \\
\text { załatwio- } \\
\text { nych }\end{array}$ & $\begin{array}{c}\text { Kwota } \\
\text { zaległości } \\
\text { wyegzekwo- } \\
\text { wanych }\end{array}$ & $\begin{array}{c}\text { Efektywność } \\
\text { tytułów } \\
\text { załatwionych } \\
\mathbf{4 : 2}\end{array}$ & $\begin{array}{c}\text { Efektywność } \\
\text { należności } \\
\text { wyegzekwo- } \\
\text { wanych } \\
5: 3\end{array}$ \\
\hline 1 & 2 & 3 & 4 & 5 & 6 & 7 \\
\hline 2010 & 2546 & 10242678 & 1237 & 2736269 & 48,59 & 26,71 \\
\hline 2011 & 2606 & 11010725 & 1291 & 2960818 & 49,54 & 26,89 \\
\hline 2012 & 2697 & 13120801 & 1306 & 3221568 & 48,42 & 24,55 \\
\hline 2013 & 2689 & 14097323 & 1300 & 3155476 & 48,34 & 22,38 \\
\hline 2014 & 2476 & 12173424 & 1310 & 2973621 & 52,91 & 24,42 \\
\hline
\end{tabular}

Źródło: opracowanie własne na podstawie danych uzyskanych z Ministerstwa Finansów

Odnosząc się do powyższych danych należy stwierdzić, iż efektywność poszczególnych należności stanowi, jak już wyżej wspomniano, poważny problem. Egzekucja należności stanowiących dochód budżetu państwa nie znajduje się na wysokim poziomie. W szczególności niepokoić Ministra Finansów powinna kwota zaległości wynikająca z takich podatków, jak podatki dochodowe, podatek od towarów i usług, które są filarami jeśli chodzi o dochody budżetu państwa. Efektywność egzekucji należności stanowiących dochód budżetu państwa oscyluje $\mathrm{w}$ granicach 24\% przy zaległościach przekraczających 12 mld zł. Nieco lepiej kształtuje się efektywność egzekucji tytułów wykonawczych, bo na poziomie 
ok. 50\%. Jednak wynika to z faktu, iż załatwione zostają w dużej liczbie tytuły wykonawcze o niskich kwotach zaległości (np. podatek PIT wynikający z zeznań rocznych). Widoczne jest zmniejszenie się liczby tytułów wykonawczych do załatwienia, jak i kwota zaległości objętych tytułami wykonawczymi w $2014 \mathrm{r}$. w porównaniu do lat poprzednich.

Tab. 3. Efektywność egzekucji podatków stanowiących dochód jednostek samorządu terytorialnego pobieranych przez urzędy skarbowe w latach 2010-2014 (kwoty w zł)

\begin{tabular}{|c|c|c|c|c|c|c|}
\hline Rok & $\begin{array}{c}\text { Liczba } \\
\text { tytułów } \\
\text { wykonaw- } \\
\text { czych do } \\
\text { załatwienia }\end{array}$ & $\begin{array}{c}\text { Kwota } \\
\text { zaległości } \\
\text { objętych } \\
\text { tytułami } \\
\text { wykonaw- } \\
\text { czymi do } \\
\text { załatwienia }\end{array}$ & $\begin{array}{c}\text { Liczba } \\
\text { tytułów } \\
\text { wykonaw- } \\
\text { czych } \\
\text { załatwio- } \\
\text { nych }\end{array}$ & $\begin{array}{c}\text { Kwota } \\
\text { zaległości } \\
\text { wyegzekwo- } \\
\text { wanych }\end{array}$ & $\begin{array}{c}\text { Efektywnośćć } \\
\text { tytułów } \\
\text { załatwionych } \\
4: 2\end{array}$ & $\begin{array}{c}\text { Efektywność } \\
\text { należności } \\
\text { wyegzekwo- } \\
\text { wanych } \\
5: 3\end{array}$ \\
\hline 1 & 2 & 3 & 4 & 5 & 6 & 7 \\
\hline 2010 & 245 & 111057 & 90 & 28109 & 36,74 & 25,31 \\
\hline 2011 & 229 & 99751 & 102 & 27764 & 44,54 & 27,83 \\
\hline 2012 & 200 & 108364 & 73 & 29457 & 36,50 & 27,18 \\
\hline 2013 & 191 & 112993 & 70 & 29392 & 36,64 & 26,01 \\
\hline 2014 & 170 & 93557 & 88 & 24022 & 51,76 & 25,67 \\
\hline
\end{tabular}

Źródło: opracowanie własne na podstawie danych uzyskanych z Ministerstwa Finansów

Dochody samorządu terytorialnego to nie tylko podatki i opłaty wymienione $\mathrm{w}$ ustawie o podatkach i opłatach lokalnych ${ }^{11}$. To również daniny pobierane na podstawie innych aktów prawnych. Wśród nich należy wskazać podatek od spadków i darowizn czy podatek pobierany w formie karty podatkowej ${ }^{12}$. Są to należności, które stanowią co prawda dochód jednostek samorządu terytorialnego, jednak ich wymiar i pobór został oddany we władztwo naczelników urzędów skarbowych. Oznacza to, iż to urzędy skarbowe dokonują ich poboru, pomimo że organ samorządu jest wierzycielem. Ma to również konsekwencje, jeśli chodzi o egzekucję tych

${ }^{11}$ Ustawa z dnia 12 stycznia 1991 r. o podatkach i opłatach lokalnych, Dz. U. z 2016 r. poz. 716 z późn. zm.; D. Michta, L. Pankrac, Podatki i opłaty lokalne. Komentarz praktyczny. Orzecznictwo, Warszawa 2015, s. 11.

12 Ustawa z dnia 28 lipca 1983 r. o podatku od spadków i darowizn, Dz. U. z 2016 r. poz. 205 z późn. zm.; ustawa z dnia 20 listopada 1998 r. o zryczałtowanym podatku dochodowym od niektórych przychodów osiąganych przez osoby fizyczne, Dz. U. z 2016 r. poz. 2180 z późn. zm. 
zobowiązań ponieważ to urząd skarbowy podejmuje czynności związane z ich egzekucją (wysyła upomnienie, wystawia i kieruje do egzekucji tytuł wykonawczy $)^{13}$. Z danych zamieszczonych w Tab. 3 jasno wynika, iż liczba tytułów wykonawczych do egzekucji zmniejszyła się. Zmniejszyła się również kwota zaległości dochodzonych przez organy egzekucyjne. Jest to zapewne spowodowane zmianami, jakie zostały wprowadzone w ustawie o podatku od spadków i darowizn, które umożliwiły nabywanie majątku bez ponoszenia obciążeń podatkowych po spełnieniu określonych warunków. Niestety, pomimo to efektywność egzekucji wskazanych powyżej należności kształtuje się na poziomie $26 \%$.

Tab. 4. Efektywność egzekucji podatków i opłat lokalnych stanowiących dochód jednostek samorządu terytorialnego w latach 2010-2014 (kwoty w zł)

\begin{tabular}{|c|c|c|c|c|c|c|}
\hline Rok & $\begin{array}{c}\text { Liczba } \\
\text { tytułów } \\
\text { wykonaw- } \\
\text { czych do } \\
\text { załatwienia } \\
\text { zaległości } \\
\text { objętych } \\
\text { tytułami } \\
\text { wykonaw- } \\
\text { czymi do } \\
\text { załatwienia }\end{array}$ & $\begin{array}{c}\text { Kiczba } \\
\text { tytułów } \\
\text { wykonaw- } \\
\text { czych } \\
\text { załatwio- } \\
\text { nych }\end{array}$ & $\begin{array}{c}\text { Kwota } \\
\text { zaległości } \\
\text { wyegzekwo- } \\
\text { wanych }\end{array}$ & $\begin{array}{c}\text { Efektywnośćc } \\
\text { tytułów } \\
\text { załatwionych } \\
4: 2\end{array}$ & $\begin{array}{c}\text { Efektywność } \\
\text { należności } \\
\text { wyegzekwo- } \\
\text { wanych } \\
5: 3\end{array}$ \\
\hline 1 & 2 & 3 & 4 & 5 & 6 & 7 \\
\hline 2010 & 1230 & 869629 & 577 & 244433 & 46,91 & 28,10 \\
\hline 2011 & 1336 & 881872 & 626 & 285280 & 46,86 & 32,34 \\
\hline 2012 & 1435 & 958643 & 673 & 298640 & 46,90 & 31,15 \\
\hline 2013 & 1493 & 1050443 & 681 & 293223 & 45,61 & 27,91 \\
\hline
\end{tabular}

Źródło: opracowanie własne na podstawie danych uzyskanych z Ministerstwa Finansów

Inną grupę dochodów stanowiących dochody budżetów samorządu terytorialnego, które są podstawą ich funkcjonowania, stanowią podatki i opłaty lokalne. Są to m.in.: podatek od nieruchomości oraz od środków transportowych, a także opłaty lokalne. Efektywność należności stanowiących dochód jednostek samorządu terytorialnego nie jest wysoka, jednak jest ona wyższa niż pozostałych należności. Kształtowanie się efektywności na poziomie 30\% stanowi duży problem, zarówno dla organów egzekucyjnych, jak i wierzycieli, którzy oczekują na odzyskanie swoich należności. W przeciwieństwie do należności wskazanych w Tab. 2 i Tab. 3

${ }^{13}$ Jeżeli zaś chodzi o rozłożenie na raty podatku lub jego umorzenie, to decyzję w tej sprawie wydaje naczelnik urzędu skarbowego, jednak po otrzymaniu stanowiska organu samorządu terytorialnego wyrażonego w formie postanowienia. 
widoczna jest tendencja wzrostu liczby tytułów wykonawczych i zaległości jeśli chodzi o należności stanowiące dochód jednostek samorządu terytorialnego. Przyczyną powyższych niekorzystnych tendencji była i jest najprawdopodobniej pogarszająca się sytuacja finansowa podatników, w tym podmiotów prowadzących działalność gospodarczą. Przyczynami są również, jak wykazały wyniki kontroli NIK, nieprzestrzeganie obowiązujących przepisów rozporządzenia w sprawie wykonania niektórych przepisów ustawy o postępowaniu egzekucyjnym w administracji oraz k.p.a. ${ }^{14}$ przez wierzycieli. Jak wykazała kontrola NIK, samorządy nie przestrzegały przepisów w zakresie wysyłania upomnień do dłużników, jak również terminów wystawiania tytułów wykonawczych i przesyłania ich do urzędów skarbowych celem wszczęcia postępowania egzekucyjnego. Oczywiście należy zauważyć fakt, iż przepisy nie określają konkretnych terminów podejmowania czynności przez wierzycieli1 ${ }^{15}$, jednak uwzględniając kryterium rzetelności, winny być one podejmowane bez zbędnej zwłoki. Jakakolwiek nieuzasadniona zwłoka skraca czas na prowadzenie czynności egzekucyjnych przez właściwe organy, co stwarza ryzyko niezapewnienia skutecznego wyegzekwowania należności gminy. Bierność wierzycieli w tym zakresie jest negatywną przesłanką, która stanowi jedną z przyczyn niskiej skuteczności egzekucji.

${ }^{14}$ Informacja o wynikach kontroli prawidłowość i skuteczność realizacji przez jednostki samorządu terytorialnego podatków lokalnych oraz dochodów z majątku, KAP-4101-004-00/2014, NIK, Warszawa 06.03.2015, s. 24.

${ }_{15}$ Jedynie w przepisach wykonawczych ustanowiono obowiązek bezwzględnego wysłania upomnienia do dłużnika, w sytuacji gdy zaległość przekroczy kwotę 10-krotności kosztów upomnienia lub na 6 miesięcy przed upływem terminu przedawnienia; rozporządzenie Ministra Finansów z dnia 30 grudnia 2015 r. w sprawie postępowania wierzycieli należności pieniężnych, Dz. U. poz. 2367, które zastąpiło rozporządzenie Ministra Finansów z dnia 20 maja 2014 r. w sprawie trybu postępowania wierzycieli należności pieniężnych przy podejmowaniu czynności zmierzających do zastosowania środków egzekucyjnych, Dz. U. poz. 656. 
Tab. 5. Efektywność egzekucji należności niepodatkowych w latach 2010-2014 (kwoty w zł)

\begin{tabular}{|c|c|c|c|c|c|c|}
\hline Rok & $\begin{array}{c}\text { Liczba } \\
\text { tytułów } \\
\text { wykonaw- } \\
\text { czych do } \\
\text { załatwienia }\end{array}$ & $\begin{array}{c}\text { Kwota } \\
\text { zaległości } \\
\text { objętych } \\
\text { tytułami } \\
\text { wykonaw- } \\
\text { czymi do } \\
\text { załatwienia }\end{array}$ & $\begin{array}{c}\text { Liczba } \\
\text { tytułów } \\
\text { wykonaw- } \\
\text { czych } \\
\text { załatwion- } \\
\text { ych }\end{array}$ & $\begin{array}{c}\text { Kwota } \\
\text { zaległości } \\
\text { wyegzekwo- } \\
\text { wanych }\end{array}$ & $\begin{array}{c}\text { Efektywnośćć } \\
\text { tytułów } \\
\text { załatwionych } \\
\mathbf{4} \mathbf{2}\end{array}$ & $\begin{array}{c}\text { Efektywność } \\
\text { należności } \\
\text { wyegzekwo- } \\
\text { wanych } \\
5: 3\end{array}$ \\
\hline 1 & 2 & 3 & 4 & 5 & 6 & 7 \\
\hline 2010 & 14322 & 5995231 & 5060 & 744117 & 35,33 & 12,41 \\
\hline 2011 & 14911 & 6168462 & 5504 & 762980 & 36,91 & 12,37 \\
\hline 2012 & 15431 & 7633635 & 5643 & 861484 & 36,57 & 11,28 \\
\hline 2013 & 17052 & 8415600 & 6312 & 926738 & 37,01 & 11,01 \\
\hline 2014 & 16719 & 8117962 & 7342 & 914482 & 43,91 & 11,26 \\
\hline
\end{tabular}

Źródło: opracowanie własne na podstawie danych uzyskanych z Ministerstwa Finansów

Ostatnią grupa którą wydzielono dla potrzeb opracowania, z całości egzekwowanych należności, są należności niepodatkowe stanowiące dochody, innych niż budżet państwa i samorządy terytorialne, organów publicznoprawnych. Są to należności przekazane do egzekucji na mocy innych aktów prawnych niż ordynacja podatkowa czy ustawy podatkowe. W grupie tej znajdują się m.in. grzywny, mandaty karne, należności za zniszczone mienie przez osadzonych w zakładach karnych, zaliczki alimentacyjne czy należności cywilnoprawne przekazane do egzekucji w związku ze zbiegiem egzekucji sądowej i administracyjnej. Efektywność przedmiotowych należności jest w porównaniu z należnościami podatkowymi na bardzo niskim poziomie. Nie bez znaczenia pozostaje fakt, iż jest to najliczniejsza grupa zaległości, na co wskazuje liczba tytułów wykonawczych. Efektywność przedmiotowych zaległości kształtująca się na poziomie $11 \%$ nie daje powodów do satysfakcji organom egzekucyjnym. Nawet efektywność egzekucji tytułów wykonawczych na poziomie ok. $40 \%$ nie napawa optymizmem. Wynika to raczej z faktu, że znaczna część należności to grzywny wymierzane przez Policję lub Inspekcję Transportu Drogowego o niskiej wartości, co powoduje, iż zostaje zakończona egzekucja tytułu wykonawczego, jednak na niską kwotę. 


\section{Wnioski de lege lata i de lege ferenda}

Przyczyn niskiej niestety efektywności egzekucji jest wiele. Wpływ na to mają różne czynniki. Jedne są zależne od działania administracji publicznej, inne od ustawodawcy, na działania którego organy egzekucyjne nie mają wpływu. Do czynników, na które organy egzekucyjne nie mają wpływu, pomimo starań w podejmowaniu czynności egzekucyjnych, należą m.in.: trudna sytuacja finansowa zobowiązanych, brak składników majątkowych podlegających egzekucji, brak zainteresowania nabyciem zajętych składników majątku czy prowadzenie działalności z wykorzystaniem majątku dzierżawionego, leasingowanego oraz kredytowanego. Problemem jest także przeciągające się dostarczanie niezbędnej korespondencji, a to ze względu na częste zmiany miejsc zamieszkania przez dłużników czy nieprowadzenie działalności pod adresem wskazanym w danych rejestrowych. Na niską efektywność wpływ miały zapewne popełniane błędy i zaniedbania wierzycieli, w tym urzędów skarbowych. Były to opóźnienia w wysyłaniu upomnień i tytułów wykonawczych, podejmowanie czynności egzekucyjnych ze znaczną zwłoką lub nieuzasadnione przerwy między poszczególnymi czynnościami, niewykorzystywanie informacji o posiadanym majątku, zaniechania poszukiwania składników majątkowych czy w skrajnych przypadkach niepodejmowanie w ogóle postępowania egzekucyjnego ${ }^{16}$. Wskazane powyżej przyczyny naruszają często ustanowione w ustawie zasady: zagrożenia, stosowania środków przewidzianych w ustawie, obligatoryjności czy celowości ${ }^{17}$.

Zwiększenie efektywności egzekucji uwarunkowane jest nie tylko podjęciem w szerszym zakresie działań (zarządczych i kontrolnych) zapewniających wyeliminowanie przypadków niepodejmowania postępowania egzekucyjnego czy unikanie nieuzasadnionych opóźnień w wystawianiu upomnień oraz tytułów wykonawczych. Należy mieć także na uwadze fakt, iż ustawa o postępowaniu egzekucyjnym w art. 6 nakazuje wierzycielowi brać czynny udział w inicjowaniu postępowania egzekucyjnego.

${ }^{16}$ Informacja o wynikach kontroli egzekwowania przez naczelników urzędów skarbowych zaległości podatkowych i niepodatkowych, 79/2008/P07031/KBF, NIK, Warszawa 2009, s. 9.

17 R. Hauser, A. Skoczylas (red.), Postępowanie egzekucyjne w administracji. Komentarz, Warszawa 2014, s. 54 i n.; Z. Leoński, Administracyjne postępowanie egzekucyjne. Problemy węzłowe, Poznań 2003, s. 75-83; K. Chorąży, W. Taras, A. Wróbel, Postępowanie administracyjne, egzekucyjne i sądowoadministracyjne, Zakamycze 2005, s. 237. 
Również rozporządzenie Ministra Finansów wskazuje na odpowiednie zachowanie się wierzycieli, jeżeli stwierdzony jest brak wykonania obowiązku przez zobowiązanego ${ }^{18}$. W szczególności $\S 4$, § 5, § 9 oraz $\S 15$ powołanego rozporządzenia nakładają na wierzyciela obowiązek systematycznej kontroli terminowości zapłaty zobowiązań pieniężnych oraz sposób komunikowania się i informowania zobowiązanego o obowiązku uregulowania należności lub zagrożeniu skierowania roszczenia na drogę postępowania egzekucyjnego. Ważne jest również podejmowanie innych czynności, takich jak zabezpieczenie należności poprzez wpis hipotek czy ustanawiania zastawów skarbowych ${ }^{19}$. Być może wpływ na niską efektywność egzekucji ma fakt, że zobowiązania podatkowe nie korzystają z pierwszeństwa zaspokojenia. Ujemny wpływ na skuteczność egzekucji ma również to, że hipoteka ustawowa i zastaw ustawowy zostały zastąpione hipoteką przymusową i zastawem skarbowym.

Zarówno państwo, jak i doktryna poszukują rozwiązań tego problemu. Wskazuje się na wiele ułomności w obowiązującej ustawie oraz w funkcjonowaniu organów egzekucyjnych. Jednym z krytyków wielu rozwiązań jest cytowany już M. Staniszewski ${ }^{20}$. Jakkolwiek z wieloma argumentami przedstawianymi przez M. Staniszewskiego należy się zgodzić i liczyć na ustawodawcę, który dokona stosownych zmian, to do niektórych, skromnym zdaniem autora, należy odnieść się krytycznie. Jedną z kwestii, z którą nie zgadza się autor niniejszego opracowania, jest likwidacja wynagrodzenia prowizyjnego dla pracowników działów egzekucji ${ }^{21}$. Wynagrodzenie prowizyjne być może jest „niesprawiedliwe”, jednak to ono

${ }^{18}$ Rozporządzenie Ministra Finansów z dnia 30 grudnia 2015 r. w sprawie postępowania wierzycieli należności pieniężnych, Dz. U. poz. 2367.

$19 \mathrm{Na}$ ten aspekt działalności wierzycieli zwrócono uwage w: P. Możyłowski, Wykorzystanie hipoteki $i$ zastawu jako form zabezpieczenia zobowiąań podatkowych przez wybrane jednostki samorządu terytorialnego województwa mazowieckiego. Zarys problemu, [w:] S. Sagan M. Sitek (red.), Bariery, wyzwania i perspektywy przekształceń samorzadu terytorialnego w Polsce, Józefów 2016, s. 37 oraz P. Możyłowski, Przedawnienie i zabezpieczenie zaległości podatkowych z tytułu podatków lokalnych w gminach w latach 2010-2015, [w:] E. Markowska-Bzducha, P. Możyłowski, T. Śmietanka (red.), Finanse samorząu terytorialnego w Polsce - problemy i wyzwania, Radom 2016, s. 227.

${ }^{20}$ M. Staniszewski, Uciażliwość a skuteczność egzekucji, s. 56-63.

${ }^{21} \mathrm{~W}$ takim razie należałoby znieść wszystkie dostępne dodatki i to nie tylko w urzędach skarbowych ale w urzędach kontroli skarbowej, izbach skarbowych czy Ministerstwie Finansów. Są to m.in. różnego rodzaju dodatki funkcyjne, dodatek kontrolerski. Bo przecież inspektorzy skarbowi otrzymują już wynagrodzenie za samo zatrudnienie $\mathrm{w}$ danej instytucji, więc czemu otrzymują dodatki kontrolerskie. 
powoduje, że w działach egzekucji jeszcze ktoś pracuje, a zwłaszcza w dużych miastach. Obciążenie pracą pracowników zajmujących się egzekucją jest dużo większe niż innych działów urzędów. Kształtuje się ono różnie w zależności od wielkości urzędu. I tak np. w tzw. dużych urzędach liczba tytułów wykonawczych przypadających na pracownika może wynosić kilkaset sztuk rocznie, aby osiągnąć poziom kilku lub kilkunastu tysięcy tytułów na osobę. Według danych uzyskanych z Ministerstwa Finansów w działach egzekucji w latach 2010-2014 zatrudnionych było średnio 4500 osób, co oznacza, że na każdego pracownika przypadało ok. 4500 tytułów wykonawczych. Nie wszyscy pracownicy zajmują się bezpośrednio egzekucja, więc rozkład ten będzie jeszcze inny ${ }^{22}$. Jeśli weźmiemy dodatkowo pod uwagę liczbę podejmowanych czynności czy kilkakrotne stosowanie środków egzekucyjnych, jeżeli wcześniej zastosowane okażą się nieskuteczne, to obciążenie pracą jest naprawdę duże. Zatem gdyby nie wynagrodzenia prowizyjne, to naczelnicy mieliby problemy z obsadą tak obciążonych stanowisk ${ }^{23}$.

Nie jest również uzasadnione proponowanie ustanowienia zakazu prowadzenia działalności gospodarczej jako nowego środka egzekucyjnego. Instytucja zakazu prowadzenia działalności gospodarczej istnieje już w porządku prawnym, a konkretnie w przepisach art. 373 ustawy z dnia 28 lutego 2003 r. - Prawo upadłościowe ${ }^{24}$. Wierzyciele i organy egzekucyjne mają także możliwość skorzystania z instytucji wyjawienia mająt$\mathrm{ku}^{25}$. Wprowadzenie dodatkowych instytucji do ustawy o postępowaniu egzekucyjnym jeszcze bardziej skomplikuje jej konstrukcję, a to na pewno nie wpłynie na poprawę efektywności egzekucji. Autor opracowania jest

${ }^{22}$ Autor, pracując w dziale egzekucji urzędu skarbowego, prowadził egzekucję na podstawie około 12 tys. tytułów wystawionych na około 6 tys. zobowiązanych.

${ }^{23}$ Należy liczyć na to, że ustawodawca zreformuje wreszcie system wynagrodzeń pracowników administracji państwowej, wprowadzając konkretne kryteria ich wysokości (np. wykształcenie, doświadczenie) zamiast dwóch podstawowych obecnych kryteriów, tj. uznaniowości kierowników i wysokości budżetów danej jednostki. Jest to bowiem system nieobiektywny, co oznacza, że na takich samych stanowiskach w tym samym urzędzie mogą być różne wynagrodzenia. Zresztą wynagrodzenie na poziomie 2300 zł brutto może będzie atrakcyjne w małej miejscowości, ale nie w dużych miastach.

${ }^{24}$ Dz. U. z 2016 r. poz. 2171 z późn. zm.

${ }^{25}$ O czym stanowią: art. 71 ustawy o postępowaniu egzekucyjnym oraz art. 913 ustawy z dnia 17 listopada 1964 r. - Kodeks postępowania cywilnego, Dz. U. z 2016 r. poz. 1822 z późn. zm. 
zdania $^{26}$, że należałoby zmienić przepisy i system orzekania w sprawach gospodarczych. A to dlatego, że dłużnicy nauczyli się już wykorzystywać istniejące przepisy. Ponad to ustanowiony zakaz prowadzenia działalności gospodarczej nie oznacza wcale, że dłużnik nie rozpocznie prowadzenia działalności gospodarczej na kogoś z członków swojej rodziny. W podobnym tonie należy odnieść się do propozycji ustanowienia zakazu korzystania z prawa jazdy przez dłużnika jako środka egzekucyjnego.

Z drugiej strony wprowadzenie nowych środków egzekucyjnych być może odniosłoby jakiś skutek, ale najprawdopodobniej odwrotny od zamierzonego. W wielu przypadkach zastosowanie takiego środka uniemożliwiłoby całkowicie osiąganie dochodów przez zobowiązanego, a nie wszyscy oni są uporczywymi dłużnikami. Część z nich popadła w kłopoty finansowe przez przypadek, w wyniku kryzysu gospodarczego czy oszukania przez kontrahenta ${ }^{27}$. Wprowadzenie zakazu prowadzenia pojazdów czy prowadzenia działalności gospodarczej do ustawy jako środków egzekucyjnych umożliwiłoby dłużnikom wnoszenie zarzutów, bowiem mogliby oni twierdzić, że jest to zbyt uciążliwy środek, co jeszcze bardziej wpłynęłoby na obciążenie pracy organów egzekucyjnych, które zamiast zajmować się egzekucją zaległości prowadziłyby coraz więcej postępowań administracyjnych.

Należy w tym miejscu zauważyć, iż ustawodawca zmienił zasady wszczynania i prowadzenia egzekucji z nieruchomości. Jest to pozytywna zmiana jaka nastąpiła w związku z nowelizacją ustawy o postępowaniu egzekucyjnym w 2013 r. ${ }^{28}$ Ustawodawca dokonał zmiany przepisów art. 110 ustawy egzekucyjnej, która ułatwia obecnie wszczęcie egzekucji z nieruchomości i niejako zlikwidowała „parasol ochronny” dla dłużników.

${ }^{26}$ Które poparte jest wieloletnią praktyką w tej materii. Niestety, z racji obowiązujących zakazów dotyczących ujawniania tajemnicy służbowej - pomimo niepozostawania już w stosunku pracy - autor nie może wyczerpująco przedstawić swoich argumentów, choć uczestniczył w wielu czynnościach przez sądami jako pełnomocnik naczelnika urzędu skarbowego.

${ }^{27}$ Na tej płaszczyźnie zarówno ustawodawca, jak i przede wszystkim sądy mają duże pole do popisu, bowiem nie potrafią się uporać ze sprawami gospodarczymi, o czym świadczą nasze pozycje w rankingach prowadzonych przez Bank Światowy. Autor zna przypadki, gdzie sprawy o niezapłacone należności trwają już kilka lat, natomiast firma już nie istnieje, bowiem istniejące zaległości oraz działania organów egzekucyjnych doprowadziły do jej likwidacji. W przypadku spornej wierzytelności nieskuteczny staje się zastosowany środek egzekucyjny, jakim jest zajęcie wierzytelności pieniężnej.

${ }^{28}$ Ustawa z dnia 11 października 2013 r. o wzajemnej pomocy przy dochodzeniu podatków, należności celnych i innych należności pieniężnych, Dz. U. poz. 1289 z późn. zm. 
Uchylając § 1-3 art. 110 ustawy o postępowaniu egzekucyjnym w administracji umożliwiono natychmiastowe wszczęcie egzekucji z nieruchomości należącej do dłużnika. Od 2013 r. ani organ egzekucyjny, ani wierzyciel nie muszą już wykazywać całkowitej lub częściowej bezskuteczności postępowania egzekucyjnego, które były warunkami wszczęcia egzekucji z nieruchomości. Oznacza to, że ustawodawca nie traktuje już tego środka egzekucyjnego jako najbardziej dolegliwego, który dotychczas musiał być poprzedzony zastosowaniem pozostałych środków. Wprowadzona zmiana ma za zadanie zdyscyplinować zarówno dłużników, jak i wierzycieli oraz organy egzekucyjne. Ci pierwsi mają przekonać się o szybkości egzekucji i utracie przeświadczenia, że postępowanie egzekucyjne prowadzone będzie latami. Ci drudzy otrzymali od ustawodawcy środek, który ma wzmóc ich działania i przyspieszyć kończenie egzekucji ${ }^{29}$.

W wielu opracowaniach wskazuje się krytyczne uwagi dotyczące prowadzonych postępowań egzekucyjnych przez organy egzekucyjne. Niestety nie wskazuje się jednocześnie na bierność wierzycieli w tym zakresie. Natomiast wyraźnie należy wskazać, iż to wierzyciel jest inicjatorem postępowania egzekucyjnego i powinien także pamiętać, że to od jego aktywności uzależnione jest szybkie i efektywne zakończenie egzekucji.

\section{Zakończenie}

Zatem, jak wskazano w niniejszym opracowaniu, efektywność egzekucji uzależniona jest od wielu czynników. Oczywiście, w znacznej mierze odpowiedzialny za nią jest organ egzekucyjny. Jednak bez odpowiedniej współpracy z wierzycielami oraz innymi organami administracji publicznej czy wymiaru sprawiedliwości efektywność ta nie będzie wysoka. Nie należy również poszerzać katalogu środków egzekucyjnych, bo ten jest wystarczający. Należy raczej dążyć do wzmocnienia pozycji organu egze-

${ }^{29}$ Składając wraz z tytułem wykonawczym wniosek o wszczęcie egzekucji z nieruchomości wierzyciel winien wykazać, iż zebrany materiał dowodowy wskazuje na brak innego majątku, z którego można by przeprowadzić egzekucję. Jest to ważne, bowiem właśnie organ egzekucyjny jest „gospodarzem” postępowania egzekucyjnego i winien postępować zgodnie z zasadą stosowania najmniej uciążliwego środka egzekucyjnego i nie jest związany wnioskiem wierzyciela. Zebranie materiału na temat źródeł dochodów i majątku dłużnika umożliwia znowelizowany art. 36 ustawy o postępowaniu egzekucyjnym. 
kucyjnego oraz stosowanych przez niego środków egzekucyjnych. Ważne jest także to, aby wprowadzane zmiany w egzekucji z jednej strony łagodziły jej uciążliwość, w szczególności w początkowym etapie, a z drugiej następowało zwiększanie jej efektywności. Ustawodawca winien wyważyć obydwie przesłanki w taki sposób, aby niejako współgrały ze sobą. A to dlatego, że egzekucja jest często bardzo uciążliwa dla uczciwych podatników i zarazem nieskuteczna wobec oszustów podatkowych. Organy egzekucyjne winny koncentrować się na wyeliminowaniu sytuacji, w których w ciągu kilkunastu dni od wszczęcia postępowania egzekucyjnego doprowadza się do likwidacji podmiotu, a jego właściciel zasila szeregi beneficjentów pomocy społecznej. Ponadto organy sprawujące nadzór nad działaniami wierzycieli winny położyć nacisk na sprawdzanie wywiązywania się przez nich z obowiązku podejmowania działań „przedwindykacyjnych", co powinno jeszcze bardziej przełożyć się na wywiązywanie z nałożonych obowiązków.

Słowa kluczowe: efektywność egzekucji, postępowanie administracyjne, postępowanie egzekucyjne, należności publicznoprawne, dochody podatkowe

\section{Bibliografia}

Chorąży K., Taras W., Wróbel A., Postępowanie administracyjne, egzekucyjne i sadowoadministracyjne, Zakamycze 2005.

Hauser R., Skoczylas A. (red.), Postępowanie egzekucyjne w administracji. Komentarz, Warszawa 2014.

Jędrzejewski T., Masternak M., Rączka P., Administracyjne postępowanie egzekucyjne, Toruń 2006, s. 27.

Karpiuk M., Egzekucja administracyjna należności stanowiacych dochód państwa oraz jednostek samorządu terytorialnego na przykładzie województwa mazowieckiego, „Studia Prawnicze i Administracyjne” 2010, nr 1.

Kmiecik Z., Postępowanie administracyjne, postępowanie egzekucyjne w administracji i postępowanie sadowoadministracyjne, Warszawa 2014.

Leoński Z., Administracyjne postępowanie egzekucyjne. Problemy węzłowe, Poznań 2003.

Małecka-Ziembińska E., Efektywność fiskalna podatku dochodowego od osób fizycznych w Polsce, Poznań 2012.

Michta D., Pankrac L., Podatki i opłaty lokalne. Komentarz praktyczny. Orzecznictwo, Warszawa 2015. 
Możyłowski P., Przedawnienie i zabezpieczenie zaległości podatkowych z tytułu podatków lokalnych w gminach w latach 2010-2015, [w:] E. Markowska-Bzducha, P. Możyłowski, T. Śmietanka (red.), Finanse samorzadu terytorialnego w Polsce - problemy i wyzwania, Radom 2016.

Możyłowski P., Wykorzystanie hipoteki $i$ zastawu jako form zabezpieczenia zobowiazań podatkowych przez wybrane jednostki samorzadu terytorialnego województwa mazowieckiego. Zarys problemu, [w:] S. Sagan M. Sitek (red.), Bariery, wyzwania i perspektywy przeksztatceń samorzadu terytorialnego w Polsce, Józefów 2016.

Możyłowski P., Przedsiębiorca jako zobowiazany w postępowaniu egzekucyjnym $w$ administracji. Wybrane zagadnienia, [w:] P. Możyłowski (red.), Zarzadzanie należnościami w sektorze małych i średnich przedsiębiorstw w okresie kryzysu gospodarczego, Radom 2014.

Przybysz P., Postępowanie egzekucyjne w administracji. Komentarz, Warszawa 2009.

Staniszewski M., Egzekucja obowiazków podatkowych, Warszawa 2010.

Staniszewski M., Uciażliwość a skuteczność egzekucji zobowiązań podatkowych, „Zeszyty Naukowe Uniwersytetu Szczecińskiego. Studia Administracyjne" 2011, nr 3 (652).

\section{THE EFFECTIVENESS OF ADMINISTRATIVE ENFORCEMENT BETWEEN YEAR 2010 AND 2014}

\section{$S \mathbf{u m} \mathbf{m}$ a $\mathbf{r} \mathbf{y}$}

The effectiveness of enforcement is important from the point of view both the state budget revenues and those of local government. Forcing the implementation of tax obligations prevent from unfairness in the rules imposed by the state and acting on behalf of it the public authorities, as well as a lack of conviction about the need to be right with the law. The aim of this study is to present the efficiency of payment of tax and non-tax charges. The author analyzed the collected data and indicated difficulties in the effective enforcement of the charges by the enforcement authorities. In addition the author described "disability" of the enforcement proceedings and moreover the passivity of the creditors. The shown data demonstrate low awareness of creditors about the possible forms of cooperation with law enforcement agencies and the ability to maintain debt what is leading to low efficiency of their use. The conclusions drawn by the author coincide with those resulting from the information audit conducted by the SCC. The contents of the development results of the analysis were in some places enriched by observations made by the author as a former employee of the enforcement authority.

Key words: effectiveness of enforcement, administrative proceedings, enforcement proceedings, public liabilities, income taxes 


\title{
ЭФФЕКТИВНОСТЬ АДМИНИСТРАТИВНОГО ИСПОЛНИТЕЯЬНОГО ПРОИЗВОДСТВА В ПОЯЬШЕ В 2010-2014 ГОДАХ
}

\author{
P е 3 ю м e
}

Эффективность исполнительного производства является важной с точки зрения доходов в бюджет как государства, так и раздичных уровней местного самоуправления. Принуждения исполнения налоговых обязанностей предотвращает нечестность в реализации наложенного государством и действующими от его имени административно-публичными органами обязанности, а также убеждению о отсутствии необходимости подчинения праву. Целью разработки является представление эффективности налоговых и неналоговых оплат. Автор, анализируя добытые данные, указывает на трудности в эффективном выполнении надлежащей суммы через исполнительные органы. В размышлениях, кроме представления «порока» положений, регулирующих исполнительное производство, были также затронуты вопросы пассивности кредиторов. Представленные данные свидетельствуют о низком сознании кредиторов о возможных формах сотрудничества с исполнительными органами, а также о возможностях обеспечения надлежащей суммы и низкой эффективности их использования. Выводы, сделанные автором, покрываются с теми, которые возникают из после контрольной информации, проведенной NIK (Верховная контрольная палата).

В содержания разработки результаты анализа юридических текстов и представленных данных были в некоторых местах обогащены замечаниями, возникающими из профессиональной практики автора, как бывшего работника исполнительного органа.

Ключевые слова: эффективность исполнения, административаное производство, исподнительное производство, публично-юридические выплаты, налоговые доходы 